\title{
PERSEPSI ULAMA BANGKA BELITUNG TENTANG TEORI KHILAFAH DAN IMPLIKASINYA TERHADAP UKLHWAH ISLAMIYAH DAN UKHUWAH BASYARIYAH DALAM KEUTUHAN NKRI DI BANGKA BELITUNG
}

\author{
Suparta \\ Institut Agama Islam Syaikh Abdurrahman Siddik Bangka Belitung \\ Jl. Pahlawan 12 Petaling, Bangka, Kepulauan Bangka Belitung, 33173 \\ E-mail: partasuparta23@yahoo.co.id
}

\begin{tabular}{c|c|c}
\hline Received: & Revised: & Approved: \\
18/10/2018 & $23 / 11 / 2018$ & $23 / 11 / 2018$ \\
\hline
\end{tabular}

DOI: http:/ /dx.doi.org/10.32332/akademika.v23i2.1237

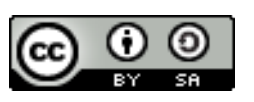

Persepsi Ulama Bangka Belitung tentang Teori Khilafah dan Implikasinya Terhadap Uklhwah Islamiyah dan Ukhuwah Basyariyah dalam Keutuhan NKRI di Bangka Belitung Licensed Under a Creative Commons Attribution-ShareAlike

4.0 International License

\begin{abstract}
This study examines the perceptions of the Ulama ini Bangka Belitung about the concept of khilafah and its implications for Ukhwah Islmaiyah, Ukhuwah Basyariyah, and Ukhuwah Wathaniyah in the integrity of the Unity Republic of Indonesia in Bangka Belitung itself. As for the research method used in this study was field research. The results of the study show that the Bangka Belitung Ulema have the same majority perception of the establishment of the Islamic Khilafah, the Khilafah in Indonesia is still not enforceable because every ulama understands the Khilafah. This happened because the Ulama had no agreement and understanding about the Khilafah. The implications of the establishment of the Islamic Khilafah on Ukhwah Islmaiyah can lead to schismatic divisions among Muslims,
\end{abstract}


the Implications of the Khilafah to Ukhuwah Basyariyah. where Indonesia has diverse tribes, races and religions. If the Khilafah is enforced upright it will become a horizontal conflict, namely the conflict between Muslims themselves and inter-religious conflict which makes the image of Muslims considered intolerant in the eyes of Indonesia and International. In addition, vertical conflict is the existence of conflict between Muslims who uphold the Khilafah with the Indonesian government and national figures and ulama who are Muslim who have not been Pro against the Caliphate. If this conflict occurs then what happens next is a split in the government and does not rule out the possibility of bloodshed. Finally, the implications for Ukhuwah Wathaniyah. In the slogan "Hubbul Wathan Minal Iman" (love of water or state is a part of Faith. This motto is one of the reasons the santri and Muslims strive for Indonesian independence from colonialism.

Keywords: Caliphate, Ulama, and Bangka Belitung.

\section{Abstrak}

Penelitian ini mengkaji persepsi Ulama Bangka Belitung tentang konsep khilafah serta implikasinya terhadap Ukhwah Islmaiyah,Ukhuwah Basyariyah, dan Ukhuwah Wathaniyah dalam keutuhan NKRI di Bangka Belitung sendiri. Adapun metode penelitian yang digunakan dalam penelitian ini adalah jenis penelitian lapangan (field research) yang berbentuk deskriptif kualitiatif. Adapun hasil penelitian adalah Ulama Bangka Belitung memiliki persepsi yang mayoritas sama terhadap penegakkan Khilafah Islamiyah yaitu khilafah di Indonesia masih belum bisa ditegakkan karena setiap ulama berbeda paham tentang khilafah. Hal ini terjadi disebabkan para ulama belum ada kesepakatan dan kesepahaman tentang khilafah. Implikasi penegakkan khilafah islamiyah terhadap ukhwah islmaiyah dapat menimbulkan perpecahan persaudaran di anatra kaum muslimin, Implikasi khilafah terhadap Ukhuwah Basyariyah. dimana Indonesia memiliki suku, ras dan agama yang beraneka ragam. Jika Khilafah dipaksakan tegak maka akan menjadi Konflik horizontal yaitu konflik antar umat islam sendiri dan konflik antar umat beragama yang menjadikan image umat Islam di anggap intoleran dimata Indonesia dan International. Selain itu, Konflik vertikal yakni adanya konflik antara umat Islam yang menegakkan khilafah dengan pemerintah Indonesia dan para tokoh nasional dan ulama yang beragama Islam yang belum Pro terhadap khilafah. Bila Konflik ini terjadi maka yang terjadi adalah perpecahan dalam pemerintahan dan tidak menutup kemungkinan terjadi pertumpahan darah. Terakhir implikasi terhadap ukhuwah wathaniyah. Dalam slogan "Hubbul Wathan Minal Iman" (cinta tanai air atau negara adalah sebagaian dari Iman. Semboyan ini menjadi salah satu alasan para santri dan umat Islam gigih memperjuangkan kemerdekaan Indonesia dari Penjajahan.

Kata Kunci: Khilafah, Ulama, dan Bangka belitung. 


\section{A. Pendahuluan}

Akhir-akhir ini sebagian Umat Islam Indonesia sedang menunjukkan kekuatannya terhadap "musuh-musuh" Islam baik musuh yang ada di Indonesia maupun musuh Islam yang ada di dunia. Faktanya sudah beberapa kali aksi yang diikuti oleh ribuan bahkan jutaan umat Islam yang ada diberbagai daerah di Indonesia. Puncaknya, aksi-aksi besar ini diadakan mulai tanggal 4 November 2016 (411), tanggal 2 Desember 2016 (212), tanggal 4 Desember 2016 (412) dan terakhir pada tanggal 11 Februari 2017. Setiap aksi tersebut selalu diikuti oleh ribuan bahkan sampai jutaan umat Islam yang ada di Indonesia. .

Ketika aksi-aksi tersebut ditinjau dari aspek psikologis maka dapat diasumsikan bahwa aksi-aksi tersebut adalah bagian dari ekspresi jiwa umat Islam yang selama ini terpendam atau merasa termarginalkan. Jika dilihat dari aspek sosial maka aksi - aksi tersebut merupakan salah satu strategi komunikasi sosial yang ditujukan kepada penguasa agar lebih peduli dalam penegakkan keadilan sosial. Kedua persfektif ini menurut sebagian umat islam masih belum begitu tajam perdebatannya. Akan tetapi jika aksi-aksi ini dikorelasikan dengan embrio bangkitnya Khilafah Islamiyah maka disinilah yang menimbulkan perdebatan antar umat Islam yang bisa menyebabkan konflik antar sesama umat Islam. Karena kenyataannya dalam tubuh umat Islam sendiri memiliki paradigma dan persepsi yang berbeda-beda tentang sistem Khilafah Islamiyah.

Perbedaan pendapat ini tentunya dikarenakan bedanya paradigma atau sudut pandang dalam menafsirkan konsep Khilafah Islamiyah itu sendiri. Hal ini tergantung pada konsep relasi antara agama dan negara. Apakah agama negara itu memiliki kesatuan atau terpisah. Fazlur Rahman misalnya dalam pengantar bukunya mengatakan bahwa antara agama dan negara memiliki hubungan yang dialektis ${ }^{1}$. Persoalannya adalah apakah agama yang berperan sebagai penentu jalannya sebuah negara atau sebaliknya negara yang menentukan dinamika agama. Ada yang mengatakan bahwa negaralah yang mememiliki peranan penting dalam mengatur 1982).

${ }^{1}$ Fazlur Rahman, Islam (Chicago \& London: The University of Chicago Press, 
dinamika agama karena melalui kekuasaan atau tatanan sosial politik maka ajaran agama dapat berkembang dengan pesat seperti yang rasul contohkan pada masa di Madinah.

Sementara ada juga yang berasumsi bahwa perkembangan agama bukan disebabkan oleh realitas kekuasaan sosial politik akan tetapi agama bisa berkembang karena oleh para penganutnya sendiri. Opini inilah yang mengatakan bahwa agamalah yang paling berperan menentukan jalannya negara, sehingga agama harus dijadikan panglima untuk mengatur seluruh tatanan kenegaraan baik yang berkaitan dengan masalah politik, sosial, ekonomi, pendidikan, kesehatan maupun yang lainnya. Dengan kata lain penerapan syari'at Islam harus diimplementasikan secara kaffah (totalitas) bukan setengah-setengah. Kelompok inilah yang memiliki keyakinan bahwa negara akan sukses dan jaya jika sistem pemerintahannya menggunakan sistem khilafah ${ }^{2}$

Bila dikorelasikan dengan kondisi Indonesia maka perbedaan dan perdebatan yang sering muncul adalah ketika ada sebagian kelompok yang menginginkan negara Indonesia menjadi negara yang menerapkan sistem khilafah. Perdebatan ini muncul bukan hanya pada kalangan politikus muslim atau antara intelektual muslim akan tetapi juga terjadi perdebatan antara para ulama. Ada ulama yang masih mempertahankan negara kesatuan Republik Indonesia yang berdasarkan pancasila dan ada juga yang ingin merubahnya berdasarkan dengan syari'at Islam dibawah sistem Khilafah Islamiyah. Tentunya semua ulama yang memiliki perbedaan pendapat tersebut memiliki dasar atau dalil masing-masing.

Untuk mengkaji diskursus di atas tentunya tidak valid jika hanya mengandalkan asumsi-asumsi saja, untuk itu diperlukan data konkrit sebagai bukti kebenaran. Salah satu bukti empirik dan valid adalah dengan cara melakukan penelitian yang mendalam terhadap persepsi para Ulama terhadap konsep khilafah.

${ }^{2}$ Jamal Al-Banna, Runtuhnya Negara Madinah, Islam Kemasyarakatan versus Islam Kenegaraan, terj. Jamadi Sunardi, Yogyakarta, Pilar Media, 2005, t.t., ia mengatakan kekhilafahan yang mengikuti prinsip-prinsip yang ditegakkan oleh Rasulullah saw berakhir pada masa Umar bin Khathab. Karena itu, kekhilafahan sebagai sesuatu yang mesti dalam islam. Sehingga Negara Islam Madinah merupakan eksperimen yang tunggal dan tidak akan terulang lagi karena didirikan langsung oleh Nabi Muhammad saw sebagai nabi. . 
Sebelumnya terdapat beberapa penelitian yang mengkaji tentang khilafah, Pertama, Pandangan Hizbut Tahrir Terhadap Radikalisme Gerakan Isis Dalam Menegakkan Daulah Khilafah Oleh Arif Muzayin Shofwan ${ }^{3}$ dengan hasil penelitian Hizbut Tahrir tidak sepakat dan bahkan menolak keras terhadap penegakan daulah khilafah Islam yang dilakukan ISIS dengan jalan kekerasan. Hizbut Tahrir memandang bahwa penegakan daulah khilafah Islam yang dilakukan oleh gerakan ISIS tidak memenuhi empat syarat yang ditawarkan gerakan Hizbut Tahrir. Dengan demikian, dalam pandangan Hizbut Tahrir, penegakan daulah khilafah gerakan ISIS tidak sesuai ajaran Rasulullah saw manakala mendirikan negara Islam.Banyak interpretasi ideologi al-Qur'an telah dikembangkan hingga saat ini. Salah satunya adalah interpretasi mistis (sufistik). Kedua, Perspektif Taqiyuddin Al-Nabhani Tentang Bai'at (Menggagas pembentukan Khilafah Islamiah oleh Hizb al-Tahrir) Oleh: Haris Riadi $^{4}$ dengan hasil penelitian yaitu Salah satu metode Syar'i untuk mengangkat kepala negara adalah bai'at. tentang pelaksanaan pengangkatan kepala negara dalam negara Islam adalah kandidat khalifah dibatasi oleh kaum muslim yang menjadi anggota majelis syura. karena majelis inilah yang menjadi representasi mayoritas kaum muslim. Kemudian nama-nama kandidat khalifah diajukan kepada kaum muslim. Yaitu agar mereka memilih satu orang dari kandidat itu sebagai khalifah bagi mereka. Selanjutnya dilihat siapa yang memperoleh suara paling banyak. Kemudian diambil bai'at untuk kandidat dengan suara terbanyak itu dari kaum muslim yang memilihnya maupun dari kaum muslim yang tidak memilihnya. Ketiga, Islam Dan Pencarian Identitas Politik (Ambiguitas Sistem Khilafah Dalam Institusi Politik Islam) oleh Ma'shum dengan hasil penelitian yaitu Salah satu catatan penting bahwa perumusan sistem kepemipinan pasca Nabi telah memberi inspirasi bagi perumusan panjang dan perdebatan sistem pemerintahan dalam Islam dengan tetap mengacu pada semangat yang mereka bangun melalui tiga prinsip yaitu Pertama, menekankan musyawarah dalam

\footnotetext{
${ }^{3}$ Arif Muzayin Shofwan, "Pandangan Hizbut Tahrir Terhadap Radikalisme Gerakan ISIS Dalam Menegakkan Daulah Khilafah," ADDIN 10, no. 1 (1 Februari 2016): 141, https:/ / doi.org/10.21043/addin.v10i1.1132.

${ }^{4}$ Haris Riadi, “Perspektif Taqiyuddin Al-Nabhani Tentang Bai'at," 2014, 14.
} 
menyelesaikan masalah politik dan sosial. Kedua, memberikan prioritas untuk menjadi pemimpin kepada masyarakat yang memiliki dan diterima oleh sebagian masyarakat, dan Ketiga, pernyataan terbuka oleh masyarakat tentang kesetiaan dalam mengikuti kepemimpinan mereka yang dinyatakan dalam bentuk bai'at. Perbedaan penelitian sebelumnya membawa penulis untuk melakukan penelitian tentang Persepsi Ulama Bangka Belitung Tentang Teori Khilafah Dan Implikasinya.

Penelitian ini menggunakan teknik analisis deskriptif kualitatif dengan jenis penelitian field research. Penelitian ini menggunakan teknik analisis deskriptif kualitatif dengan jenis penelitian field research Agar penelitian ini tidak terlalu luas maka peneliti membatasi obyek penelitiannya hanya di Kepulauan Bangka Belitung. Selain melihat persepsi tentang khilafah penelitian ini juga akan mencari tahu tentang implikasinya khilafah terhadap ukhwah islamiyah dan ukhwah Basyariyah.

\section{B. Khilafah Islamiyah dan Ukhuwah Islamiyah}

Berdasarkan hasil wawancara dengan para Ulama Bangka Belitung yaitu Ketua MUI Bangka Barat, Bangka Tengah, Bangka Selatan dan Ketua MUI Bangka Belitung serta Pimpinan NU Basel dan Pimpinan Muhammadiyah Belitung Timur dapat disimpulkan bahwa mereka berbeda paham dalam menyikapi khilafah dengan salah satu ormas yang telah dibubarkan yaitu HTI.

KH. Hasyim Sya' roni ${ }^{5}$ secara tegas mengakui khilafah memang pernah ada pada masa Rasulullah dan Masa Khulafaurrasyidiin. Itupun yang murni berhasil menegakkan khilafah adalah Rasulullah saw ketika memimpin di kota Madinah. Setelah kepemimpinan Rasulullah saw khilafah kurang begitu sempurna dikarenakan sudah adanya berbagai kepentingan yang bernuansa politis dan ambisi duniawi. Oleh karena itu beliau mengatakan bahwa khilafah untuk tegak di Indonesia menjadi sulit bahkan sangat sulit terealisasi. Hal ini disebabkan di negara Indonesia disamping memiliki suku,

\footnotetext{
${ }^{5}$ KH.Hasyim Sya'roni, Ketua MUI Bateng, 28 April 2017, Koba.
} 
bahasa, dan agama yang beraneka ragam juga sudah memiliki dasar atau ideologi sendiri yaitu pancasila dan UUD $1945^{6}$.

Demikian juga yang dikatakan oleh KH. M.Thoha ${ }^{7}$ bahwa khilafah tidak bisa dipaksakan untuk tegak di Indonesia karena Indonesia sudah memiliki pemerintahan sendiri. Bahkan pemerintah Indonesia ini juga didirikan oleh mayoritas ulama ternama di Indonesia seperti KH. Hasyim Asy'ari sebagai sesepuh dan Tokoh Ulama dari Nahdhatul Ulama (NU). Mayoritas ulama pendiri tersebut sepakat bahwa Indonesia adalah NKRI (Negara Kesatuan Republik Indonesia) yang berdasarkan pancasila dan UUD 1945. Bahkan memiliki semboyan yang sangat bijaksana yaitu Bhineka Tunggal Ika, yang artinya walaupun kita berbeda suku, bahasa dan agama akan tetapi tetap satu yaitu Indonesia.

Hal ini senada dengan yang diungkapkan oleh Ustadz Sujoko $^{8}$ bahwa khilafah tidak cocok di Indonesia karena sudah memiliki ideologi sendiri yaitu pancasila. Jika khilafah ditegakkan berarti secara tidak langsung akan menggantikan pancasila. Padahal menurut beliau pancasila selama ini sudah terbukti bisa menyatukan bangsa Indonesia dari sabang samapi meroke. Tak terbayangkan jadinya jika dasar negara ini di rubah, bagi kita umat Islam bisa saja bergembira dengan adanya khilafah akan tetapi bagaimana dengan agama lainnya apakah mereka juga setuju? jika tidak setuju disinilah sumber malapetaka akan bermula. Bisa saja akan terjadi pertumpahan darah, peperangan dan pastinya akan menimbulkan perepecahan dinatara bangsa.

Pimpinan Pondok Pesantren Darunnjah Rias, KH. M. Alwi dan Ustadz Yanto juga sama tidak sepakat dengan adanya khilafah di Indonesia 9 . Khilafah memang bagus konsepnya akan tetapi sangat sulit direalisasikan di sebuah negara yang sudah merdeka dan sudah memiliki dasar falsafah negara. Jika dipaksakan maka khilafah bukan

\footnotetext{
${ }^{6}$ KH.Hasyim Sya' roni,.

${ }^{7}$ KH. Muhammad Thoha, Ketua Majelis Ulama Indonesia Kabupaten Bangka Barat, Wawancara, di Muntok, 12 Mei 2017.

${ }^{8}$ Ustadz Sujoko, Pimpinan Cabang Muhammadiyah Kabupaten Belitung Timur, 18 April 2017.

9 KH.Dedy Alwi dan Ustadz Yanto, Pimpinan Ponpes Miftahunnajah, Wawancara, pada tanggal 14 April dan 15 April 2017, t.t.
} 
menjadi sumber pemecah masalah justru akan menjadi sumber masalah. Bahkan dikhawatirkan ada persepsi bahwa Islam menjadi tidak ramah karena mau merubah negara yang sudah memiliki falsafah dan tatanegara sendiri. Jika saat ini negara indonesia sedang banyak masalah dan mungkin belum adil makmur dan sejahtera itu bukan karena falsafah negara nya yang salah akan tetapi karena oknumnya yang selalu berbuat masalah.

Menurut pimpinan Pondok tersebut sebenarnya yang paling penting bagi umat Islam menjalankan ajaran agamanya dengan benar. Diantaranya siapapun yang menjadi pimpinannya jika dia beragama Islam maka hiasilah kepemimpinannya dengan nilai-nilai Islam jangan justru Nilai-nilai Islam ditinggalkan. Jika interanalisasi nilai-nilai Islam dapat diejawantahkan pada setiap pemimpin Islam maka walaupun tanpa khilafah sudah terasa hidup dibawah naungan khilafah. Karena pada dasarnya islam itu ajaran yang universal yang akan selalu bermanfaat dan sesuai dengan segala zaman (masa) dan makan (tempat).

Atas dasar wawancara tersebut dapat disimpulkan bahwa para ulama bangka belitung mayoritas tidak sepaham dengan konsep khilafahnya yang ditawarkan oleh HTI. Jika hal ini dipaksakan maka akan bisa menjadi salah satu pemicu terpecahnya ukhuwah islamiyah di antara umat islam umumnya dan diantara para ulama pada khususnya.

\section{Disparitas pemahaman Khilafah dalam sebuah alasan Konflik di antara Ulama}

Merebaknya isu tentang khilafah yang digulirkan oleh salah satu Ormas Islam ternyata tidak semua ulama di Bangka Belitung bisa menerimanya. Sehingga masalah khilafah menjadi khilafiayah di antara para ulama Bangka Belitung. Dengan kata lain, ada sebagian Ulama yang Pro dengan Khilafah dan ada ulama yang Pro dengan Khilafah.

Letak perbedaan yang paling tajam yang dalam konsep khilafah dikalangan Ulama Bangka Belitung ini terletak pada perbedaan pemahaman pada kholafah yang harus di terapkan di Indonesia. Namun jika khilafah yang ditreapkan pada masa Rasulullah seluruh Ulama Bangka Belitung sepakat, karena memang pernah ada Khilafah pada masa Rasulullah saw dan dijalankan sempurna karena memang yang menjadi khalifahnya langsung Baginda Rasulullah saw. Akan tetapi, ketika khilafah 
ini dipaksakan untuk ditegakkan di Indonesia maka disisnilah mulai terjadi pro dan kontra.

Dengan adanya kontradiksi maslah khilafah ini maka jika terus dipaksakan akan menjadi sumber konflik antara para ulama yang ada di Bangka Belitung khususnya dan antara ulama yang ada di Indonesia pada umumnya. Konflik internal umat Islam ini sebenarnya jangan sampai terjadi, sebab jika terjadi konflik dalam umat Islam akan menjadi sasaran empuk bagi golongan lain yang menginginkan adanya perpecahan dalam umat islam.

Hal ini sesuai dengan hasil Wawancara dengan KH. Muhammad Thoha ${ }^{10}$ dan salah satu Pimpinan Pondok Pesantren Miftahul Jannah Rias, Toboali bapak KH.Dedy Alwi yang mengatakan bahwa desakan salah satu ormas untuk menjadikan khilafah di Indonesia merupakan salah satu sumber konflik bagi umat islam ${ }^{11}$. Hal ini disebabkan tidak semua ulama di Bangka Belitung sepakat dengan masalah tersebut. Demikian pula menurut Ustadz Yanto yang termasuk salah satu pimpinan Pondok Pesantren Miftahul Jannah mengatakan bahwa Indonesia merupakan negara yang sudah memiliki sistem dan ideologi negara yang final. Dengan adanya Pancasila dan UUD 1945 berarti Indonesia sudah memiliki falsafah sendiri. Bahkan Pancasila sangat sejalan dengan Islam dari setiap sila silanya. Untuk itu, normal saja jika khilafah dijadikan sebagai wacana, atau khazanah ilmu. Akan tetapi ketika dipaksakan menjadi sebuah sistem di sebuah negara yang sudah jelas dasar dan ideologinya seperti di Indonesia maka inilah yang menjadi masalah. Masalah tersebut bukan saja akan terjadi antara ulama dengan pemerintah dan masyarakat akan tetapi juga akan terjadi terhadap sesama ulama sendiri.

Namun demikian menurut Fajri salah satu mantan aktivis organisasi HTI Bangka Belitung, ia mengatakan bahwa khilafah tersebut tidak bertentangan dengan pancasila. Karena pada dasarnya penegakkan khilafah ini tujuannya untuk membumikan syari'ah Islam agar umat islam menjadi umat yang menjalankan syari' at islam secara Kaffah (menyeluruh) bukan setengah setengah. Salah satu cara agar syari'ah ini dapat diterapkan

${ }^{10}$ KH. Muhammad Thoha, Ketua Majelis Ulama Indonesia Kabupaten Bangka Barat, Wawancara, di Muntok.

${ }^{11}$ KH.Dedy Alwi dan Ustadz Yanto, Pimpinan Ponpes Miftahunnajah, Wawancara, pada tanggal 14 April dan 15 April 2017. 
di Indonesia dengan Kaffah maka harus dengan dengan sistem khilafah. Saat ini sistem pemerintahannya demokrasi maka jika digantikan dengan sistem khilafah maka akan lebih baik, karena sesuai dengan tuntunan Rasulullah saw.

\section{Penegakan Syariah tanpa Khilafah}

Para Ulama Bangka Belitung sepakat dalam penegakan nilai-nilai syari'ah Islam di Indonesia, karena tidak merubah falsafah Indonesia sendiri. Seperti ungkapan KH. Hasyim Sya'roni bahwa penerapan syari'ah bagi umat islam wajib karena itu merupakan ajaran yang harus dijalankan. Misalnya jika ia menjadi pimpinan seperti menjadi presiden, Gubernur atau Bupati sementara ia adalah umat islam maka harus patuh dan tunduk pada syari'at Islam. Contohnya, dalam Islam diajarkan bahwa seorang pemimpin harus amanah, maka jika ia orang islam maka harus menjadi pemimpin yang amanah. Dalam syari'at islam seorang pemimpin harus jujur maka jika pemimpinnya umat islam maka wajib menegakkan kejujjuran.

Hal ini senada dengan yang diungkapkan oleh Ustadz Sujoko dan Ketua MUI Bangka Belitung Zayadi Hamzah yang menginginkan bahwa pimpinan umat islam seharusnya menjadi warna dalam pemerintahan bukan malah diwarnai oleh paham lainnya. Sebab dalam ajaran islam sangat komprehensif, semua tatanan dan aturan baik yang berupa atura duniawi maupun ukhrowi telah ada dalam ajaran islam. Untuk itu, yang harus diterapkan dan ditunjukkan pada negara adalah implemetasi nilai nilai ajaran islamnya yang dijadikan acuan dalam bertindak dan berprilaku. Jika dalam ajaran islam ada larangan untuk berbuat dzalim maka jika ia sebagai pemimpin muslim maka jangan berbuat dzalim terhadap rakyatnya.

Demikian juga menurut Hatamar dalam suatu diskusi tertutup di Pascasarjana IAIN SAS Bangka Belitung tentang Khilafah ia mengatakan bahwa sangat berat jika khilafah ditegakkan di Indonesia, karena sejarah telah membuktikan sudah beberapa kali ada kelompok atau golongan tertentu yang akan menggantikan pancasila maka yang menentangnya bukan hanya dari kalangan non muslim akan tetapi dikalangan muslim sendiri mayoritas menolaknya. Adannya penolakannya ini membuktikan bahwa pancasila menjadi pilihan terbaik dan terbukti secara signifikan 
mampu menyatukan bangsa Indonesia yang memiliki keragaman suku, bahasa dan agama.

Namun demikian menurut beliau jika ajaran Islam diinternalisasikan atau di kolaborasikan dalam setiap aspek kehidupan baik itu pada aspek politik, aspek ekonomi, aspek pendidikan, aspek pembangunan, aspek hukum dan aspek sosial sangat setuju. Artinya ajaran Islam atau syari'ah Islam menjadi pijakan utama bagi umat islam khususnya dalam berinteraksi baik secara personal maupun sosial, baik secara horizontal maupun vertikal. Sehingga ajaran islam menjadi warna dala setiap aspek kehidupan bukan diwarnai oleh aliran atau ajaran-ajaran yang menyesatkan ${ }^{12}$.

\section{Implikasi Khilafah terhadap Ukhwah Islamiyah}

Para ulama Bangka Belitung berpendapat bahwa khilafah memang bagus, akan tetapi tidak cocok jika harus dipaksakan tegak di Indonesia. Hal ini disebabkan karena Bangsa Indonesia telah memiliki ideologi sendiri yaitu Pancasila dan UUD 1945. Jika ada kelompok yang memaksakan maka akan berimplikasi negatif terhadap ukhuwah islamiyah di Bangka Belitung dan umumnya di Indonesia. Hal ini disebabkan tidak semua ulama sepakat dengan ide khilafah ini.

Akan tetapi, jika ide Syari'ah yang harus dijalankan oleh setiap orang Islam baik sebagai pimpinan maupun masyarakat biasa maka para ulama Bangka Belitung sepakat. Harus dibedakan antara menjalankan sayari'ah dan menyasyari'ahkan bangsa. Jika menjalankan syari'ah maka yang dibidik atau orientasi utamanya adalah personal akan tetapi jika mensyari'ahkan bangsa maka orientasinya universal. Untuk itu, agar tidak terjadi perpecahan diantara umat islam maka harus ada kesepakatan bersama tentang penegakkan nilai nilai syari'ah pada umat islam bukan menegakkan Khilafah. Dengan kata lain umat Islam harus sepakat

${ }^{12}$ Hatamar, diskusi tertutup Pascasarjana IAIN SAS Babel, 23 Maret 2018 Diantara aliran atau ajaran yang bisa membahayakan di Indonesia adalah ajaran Kom unisme karena ajaran ini sangat bertentangan dengan Pancasila. Dalam ajaran komunis membolehkan sesorang tidak memeiliki agama atau tidak beragama, sementara hidup di indonesia jika berdasarkan pancasila sila pertama maka wajib setiap individu yang hidup di Indonesia memiliki agama yang diakui di Indonesia. Selain komunis ajaran yang bisa berbahaya juga adalah ajaran liberalisme yaitu sebuah ajaran yang membebaskan pemeluknya untuk memilih kehidupan sesuai dengan yang disukainya. Keduanya tentunya bertentangan dengan pancasila. . 
menghidupkan nilai -nilai keislaman dalam setiap diri umat islam agar ajaran Islam menjadi ruh dalam kehidupan berbangsa dan beragama di Indonesia.

\section{Implikasi Khilafah Islamiyah terhadap Ukhuwah Basyariyah}

\section{Islam Rahmatalil 'Alamiin}

Sebagian besar ulama bependapat bahwa komponan utama bagi agama Islam, sekaligus sebagai nilai tertinggi dari ajaran agama Islam adalah: akidah, syariah dan akhlak. Penggolongan ini didasarkan pada penjelasan Nabi Muhammad kepada malaikat Jibril mengenai arti Iman, Islam dan Ikhsan yang esensinya sama dengan akidah, syariah dan akhlak.

Akidah menurut pengertian etimologi adalah ikatan atau sangkutan. Dikatakan demikian karena ia mengikat dan menjadi sangkutan atau gantungan segala sesuatu.dalam pengertian teknis diartikan dengan iman atau keyakinan, sehingga pembahasan akidah selalu berhubungan dengan rukun iman yang menjadi asas seluruh ajaran Islam atau merupakan akidah Islam, yaitu: keyakinan kepada Allah, keyakinan kepada malaikatmalaikat, keyakinan kepada kitab-kitab suci, keyakinan kepada rasul-rasul, keyakinan kepada adanya hari kiamat dan keyakinan kepada qada' dan qadar Allah SWT.

Yang dimaksud dengan Syariah menurut etimologi adalah jalan (ke sumber atau mata air) yang harus ditempuh (oleh setiap umat Islam). Menurut istilah, syariah adalah sistem norma (kaidah) Ilahi yang mengatur hubungan manusia tehadap dirinya sendiri dan hbungan manusia dengan sesama makhluk. Kaidah yang mengatur hubungan manusia dengan Allah disebut kaidah ibadah atau kaidah Ubudiyah, sedang kaidah yang mengatur hubungan manusia dengan sesama manusia, manusia dengan dirinya sendiri dan manusia dengan sesama makhluk disebut kaidah mu'amalah.

Sedang yang disebut dengan akhlak secara etimologis, berasal dari kata akhlak, bentuk jamak dari khuluk yang berarti budi pekerti, perangai, tingkah laku atau tabiat. ${ }^{13}$ Menurut istilah, akhlak adalah keadaan yang melekat pada jiwa manusia yang dari padanya melahirkan

\footnotetext{
${ }^{13}$ Rachmat Djatmika, Sistem Etika Islam, Surabaya: Pustaka Islam, 1987, t.t.
} 
perbuatan-perbuatan tanpa melalui proses pemikiran, pertimbangan atau penelitian. ${ }^{14}$

Ketiga asas tersebut, membentuk sistem nilai yang dapat dijadikan sebagai pegangan hidup (akidah), jalan hidup (syari'ah) dan sikap hidup (akhlak), yang saling berinteraksi dalam mengatur kehidupan dan penghidupan manusia dalam semua aspek dan dimensi, baik individu maupu kelompok.

Oleh sebab itu, sebagai parameter keimanan seseorang dapat dilihat dari kebagusan ibadah dan akhlaknya, demikian halnya untuk menilai kadar peribadatan seseorang dapat dilihat dari kaidah yang melandasi dan katualisasi nilai-nilai ibadah dalam praktek amal shalehnya. Penilaian tersebut juga berlaku bagi akhlak seseorang, selain akhlak tidak dapat dipisahkan dengan akidah, akhlak juga tidak dapat dipisahkan dengan syari'ah, syari'ah memiliki lima kategori penilaian tentang perbuatan dan tingkah laku manusia, yang biasa disebut Al-Ahkam Al-Khamsah yang terdiri dari: wajib, sunnah, haram, makruh, mubah atau jaiz. ${ }^{15}$

Thoha mengelompokkan nilai-nilai ke dalam tiga wilayah, yaitu: wilayah pusat, wilayah nilai-nilai ilahiyah muamalah dan nilai-nilai insaniyah. ${ }^{16}$ Wilayah pusat merupakan pusat nilai yang berisikan inti dari nilai-nilai ilahiyah ubudiyah, yakni nilai-nilai hal. keimanan kepada Tuhan. Nilai-nilai keimanan inilah yang berikutnya akan mewarnai nilainilai lainnya, seperti nilai-nilai ilahiyah muamalah dan nilai-nilai etik insaniyah. Wilayah nilai-nilai ilahiyah muamalah adalah merupakan nilainilai terapan yang bersumber dari wahyu, sudah mulai jelas pembidangan aspek-aspek hidup yang meliputi: rasional, sosial, individual, biofisik, ekonomi, politik dan nilai estetika. Sedangkan wilayah nilai-nilai insaniyah adalah bentuk operasional dari nilai rasional, nilai soaial, nilai individual, nilai biofisik, nilai ekonomi, nilai politik, dan nilai estetika.

Itulah sebabnya dari awal sudah Allah tegaskan bahwa Islam sebagai agama yang Rahmatalil Alamiin, karena Allah mengutus Nabi Muhammad saw bukan hanya rahmat untuk orang arab saja akan tetapi

${ }^{14}$ Salim bin Ied al-Hilali, Ensiklopedi Larangan Menurut al-Quran dan as-Sunnah, terj. Abu Ihsan al-Atsari (Bogor: Pustaka Imam Syafii, 2005).

${ }^{15}$ Muhammad Daud Ali, Pendidikan Agama Islam, Jakarta: PT. Raja Grafindo Pesada, 2000, t.t.

${ }^{16}$ KH. Muhammad Thoha, Ketua Majelis Ulama Indonesia Kabupaten Bangka Barat, Wawancara, di Muntok. 
menjadi rahmat bagi seluruh alam. Hal ini sesuai dengan firman Allah dalam Al-Qur'an surat Al-Anbiya; 107 yang artinya "Dan tiadalah kami mengutus kamu, melainkan untuk (menjadi) rahmat bagi semesta alam".

Atas dasar ayat inilah akhirnya para ulama di Bangka Belitung sepakat bahwa ajaran Islam adalah ajaran yang sangat menghargai keberagaman. Dengan kata lain agama islam sudah memiliki sikap toleransi yang sangat baik sejak 14 abad yang lalu. Hal ini telah dicontohkan langsung oleh baginda Rasulullah saw, bagaimana rasul menghargai, menghorati dan berinteraksi tanpa syarat baik pada orang yang islam maupun non muslim, baik pada orang yang beriman maupun tidak beriman. Karena memang sudah menjadi sunnatullah bahwa Allah menciptakan manusia yang snagat beragam yakni bersuku-suku dan berbangsa-bangsa agar saling kenal mengenal. Hal ini sesuai dengan firman Allah swt dalam surat Al-Hujrat: 13

\section{Islam Wasathiyah lebih cocok untuk Indonesia}

Menurut KH.Muhammad Thoha ketua MUI Bangka Barat, ia mengatakan bahwa selama ini di majelis Ulama Indonesia telah disepakati model Islam yang cocok di Indonesia adalah model islam wasathiyah yakni model Islam pertengahan. Maksudnya adalah posisi Islam yang baik adalah Islam yang mengedepankan kemaslahatan umat daripada kemudharatan bagi umat ${ }^{17}$. Melalui model islam wasathan inilah akhirnya umat Islam bisa diterima dimana-mana dan bisa berada dimana-mana dengan catatan jangan sampai sampai mengenyampingkan akidahnya. Model ini khusus yang berkorelasi dengan masalah muamalah bukan masalah akidah.

Ukhuwah basyariyah yang sudah berjalan di Indonesia sudah sangat baik dengan prinsip Islam wasathannya. Jika berusaha keluar dari prinsip ini maka dikhawatirkan akan terjadi konflik yang berkepanjangan. Konflik tersebut bukan hanya terjadi antar umat beragama akan tetapi inter umat beragama juga bisa terjadi konflik. Dengan kata lain, model atau aliran keislaman yang dari luar tidak bisa dipaksakan untuk menjadi

${ }^{17}$ Hal ini sesuai dengan yang dikatakan oleh Prof.Dr. H. Nur Syam Menurutnya, Islam wasathiyah merupakan Islam yang memberikan keselamatan bagi umat manusia. bahwa Islam harus ditunjukkan sebagai agama yang memang memberikan rahmat bagi semua umat manusia. Karena itu, umat Islam harus kuat di dalam yang tentunya dapat dicapai dengan memperkuat rasa persaudaraan ukhuwah Islamiyah.( http:/ / liputanislam. com/indonesiana/sekjen-kemenag-ajak-umat-perkuat-wawasan-islam-wasathiyah/) 
model Islam di Indonesia, karena Indonesia sudah memiliki model Islam sendiri yang cocok dengan karakter Indonesia yang memiliki falsafah Pancasila dan UUD 1945 yang akhirnya memunculkan sikap Nasionalisme Ke-Indonesiaan ${ }^{18}$.

\section{Islam Nusantara Penyatu Umat di Indonesia}

Kalau Majelis Ulama Indonesia mengedepankan prinsip Islam Wasathiyah maka Nahdhatul Ulama lebih mengedepankan dengan istilah Islam Nusantara. Adapun yang dimaksud dengan Islam nusantara menurut KH. Dedi Alwi adalah Islam di Indonesia yang telah diajarkan oleh para Wali Songo sangat kental dengan berbasis budaya lokal ${ }^{19}$. Artinya Islam hadir di Indonesia khususnya di Pulau Jawa diiringi dengan budaya yang ada di daerah masing-masing. Seperti Sunan Kalijaga misalnya, ia berdakwah melalui pewayangan yang digubah materi wayangnya dengan materi Dakwah. Begitu juga dengan kebiasaan tahlilan dan halal bi halal, kebiasaan tersebut murni hanya ada di Indonesia. Tentunya masih banyak lagi di daerah -daerah tertentu yang memiliki model keislaman yang khas sesuai dengan budaya daerahnya. Hal inilah yang dikatakan dalam istilah NU Islam Nusantara, berislam dengan tidak meninggalkan budaya daerahnya masing-masing dengan catatan tidak keluar dari ajaran syari'ah dan aqidah.

${ }^{18}$ KH.Hasyim Sya'roni, Harus diingat terus bahwa nasionalisme keindonesiaan bukanlah hal yang asing bagi generasi muda Indonesia yang lahir dan hidup di bagian manapun dari negara kepulauan Indonesia yang luas, mengingat kaum muda Indonesia telah pernah mengikrarkan nasionalisme keindonesiaan ini dalam suatu sumpah pemuda pada 28 Oktober 1928 ketika Indonesia masih dalam penjajahan Belanda. Mengingat peran historis kaum muda Indonesia dalam membangun nasionalisme keindonesiaan ini, sudah seharusnya kaum muda Indonesia pada masa kini dapat membantu pemerintah pusat untuk menjalankan pemerintahan di seluruh Indonesia dengan berlandaskan hanya UUD 45 dan Pancasila. Mereka harus ikut mempertahankan Indonesia sebagai negara Pancasila, bukan negara agama apapun. Bentuk NKRI sebagai negara berideologi Pancasila dan berUUD 45 adalah satu-satunya bentuk yang paling masuk akal dan paling setia pada sejarah bagi setiap usaha membangun kerukunan antar umat-umat beragama. .

${ }_{19}$ KH.Hasyim Sya'roni, Islam nusantara adalah sebagai hasil ijma dan ijtihad para ulama nusantara dalam melakukan istinbath terhadap al-muktasab min adillatihatafshiliyah. Islam nusantara adalah idrakul hukmi min dalilihi ala sabili-rujhan. Islam nusantara memberi karakter bermazhab dalam teks-teks para ulama nusantara untuk menyambungkan kita dengan tradisi leluhur kita, untuk dihormati, dan untuk kita teladani (http:/ / kelompok8studis.blogspot.co.id/2016/04/makalah-studi-islam-tentang-islam. html). 
Dengan demikian, model Islam Nusantara ini sangat cocok untuk menjalin Ukhuwah Basyariyah, yakni hubungan atau jalinan persaudaran sesama manusia tanpa memandang manusia tersebut memiliki agama, suku dan ras yang berbeda. Hal ini berarti sesuai dengan semboyan negara Indonesia yaitu Bhineka Tunggal Ika. Hubungan yang baik antar sesama manusia di Indonesia ini akan terus baik dan bertahan jika antara sesama umat beragama tidak bergesekan. Diantara pemicu gesekan adalah jika ada ajaran atau paham yang tidak sesuai dengan kebhinekaan.

\section{Implikasi Khilafah Islamiyah terhadap Ukhuwah Basyariyah}

Meurut Sujoko salah satu Pimpinan Daerah Muhammadiyah mengatakan bahwa Khilafah bisa berimplikasi positif dan juga bisa negatif ${ }^{20}$. Berimplikasi positif bila khilafah ini sudah menjadi kesepakatan ulama se-Indonesia, tidak ada perbedaan pendapat lagi dan didukung oleh pemerintah. Jika demikian maka khilafah bisa serasi dengan ykhuwah basyariyah. Akan tetapi akan berdampak negatif terhadap ukhuwah basyariyah jika khilafah ini ditegakkan ditengah-tengah perselisihan pendapat baik di antara umat Islam maupun dalam pemerintahan. Terlebih lagi akan ditentang oleh umat beragama yang lainnya. Jika hal ini terjadi maka khilafah bukan menjadi sumber yang berkah akan tetapi justru akan menjadi sumber masalah dan sumber konflik.

Demikian juga yang dikatakan oleh KH.Hasyim Sya'roni, ukhuwah basyariyah yang ada saat ini di Indonesia sudah baik. Bila dipaksakan ditegakkan khilafah sementara belum menjadi kesepakatan atau ijma' para ulama di Indoesia maka khilafah yang diajarkan Rasulullah itu baik menjadi tidak baik. Jangan sampai ada asumsi nantinya Islam itu tidak menghargai manusia lain yang memiliki agama dan budaya yang berbeda. Agar Islam selalu baik dimata umat yang lainnya maka yang harus ditegakkan pertama kali adalah internalisasi nilai-nilai keislaman dalam kehidupan sehari-hari. Terutama nilai-nilai yang berhubungan dengan syar'ah muamalah dan akhlak.

Dari beberapa hasil wawancara dengan para ulama di atas, maka dapat disimpulkan bahwa Khilafah akan berimplikasi baik dan berkah bila sistem khilafah ini sudah menjadi Ijma' Ulama dan diizinkan oleh

${ }^{20}$ Ustadz Sujoko, Pimpinan Cabang Muhammadiyah Kabupaten Belitung Timur. 
Negara. Tetapi akan berimplikasi negatif bagi keberlangsungan ukhuwah basyariyah bila khilafah ini masih menjadi perbedaan pendapat antara ulama dalam umat islam dan Negara belum mengizinkan.

Dengan demikian implikasi khilafah akan menjadi negatif jika memang berusaha akan mengganti sistem yang sudah ada dan sudah dilaksanakan di Indonesia. Implikasi negatifnya yaitu adanya konflik antara penegak khilafah dengan pemerintah. Konflik ini bisa terjadi bukan hanya bersifat horizontal (antara internal umat Islam maupun ekternal umat islam) akan tetapi juga akan dapat terjadi konflik secara vertikal (yaitu antara penegak khilafah dengan pemerintah). Untuk itu, mayoritas umat Islam masih sepakat bahwa sistem yang sudah dijalankan saat ini sudah baik dengan catatan harus sesuai dengan nilai-nilai dasar pancasila dan UUD 1945. Walaupun menggunakan sistem demokrasi akan tetapi demokrasi yang baik untuk Indonesia adalah demokrasi yang berasaskan pancasila bukan demokrasi yang berasaskan kapitalis, leberalis maupun komunis.

\section{E. NKRI Harga Mati}

Berdasarkan hasil wawancara dengan beberapa tokoh ulama Bangka Belitung seperti KH.Hasyim Sya'roni, KH.Muhammad Thoha, Ustadz Sujoko, KH. Dedi Alwimereka sepakat bahwa NKRI adalah harga mati. Maksudnya adalah sistem Negara Kesatuan Republik Indonesia yang sudah berjalan saat ini dianggap sudah final. Hal ini dikarenakan sejak kemerdekaan Indonesia pada Tahun 1945 negara Indonesia sudah berhasil menerapkan sistem yang berdasarkan Pancasila dan UUD 1945. Sistem ini bukan hanya menjadi kebanggaan negara saja akan tetapi juga menjadi kebanggaan umat Islam, karena pancasila di susun sudah memiliki korelasi yang signifikan dengan umat Islam dari sila ke sila.

Jika dipaksakan diganti sistem apalagi sistem tersebut belum ada kesepakan dengan pemerintah dan para ulama seluruhnya maka akan bisa berimplikasi negatif dengan ukhuwah wathaniyah yang selama ini sudah berjalan dengan baik. Sebab, dalam umat Islam sudah menjadi rahasia umum digelorakan slogan Arab "Hubbul Wathan Minal Iman". Maka akibat slogan inilah yang menyebabkan nasionalisme umat Islam tumbuh dan berkembang dengan baik bahkan ada yang sampai rela mati demi mempertahankan negaramya. 
Buktinya banyak dari ulama dan umat islam yang rela berkorban tenaga, harta dan nyawa demi negara ini terjadi pada saat melawan penjajah baik pada masa penjajahan belanda maupun jepang. Pada saat itu andil ulama dan umat islam sangatlah besar, terutama ulama-ulama yang memiliki pondok pesantren dan memiliki ribuan santri. Mereka semuanya berjuang untuk kemerdekaan Indonesia.

\section{Hegemoni konsep Khilafah sebagai pemicu Friksi Kebangsaan}

Mayoritas ulama yang diwawancari di berbagai daerah yang ada di Bangka Belitung mengatakan bahwa sistem Khilafah belum cocok dilaksanakan di Indonesia. Ketidak cocokan ini bukan berarti mereka menganggap bahwa sistem khilafah itu jelek, akan tetapi disebabkan oleh sistem yang ada di Indonesia dari sejak kemerdekaan sudah memiliki model dan sistem sendiri. Oleh sebab itu, diperlukan usaha yang masif dan pendekatan persuatif yang aktif dengan berbagai pihak jika memang sistem khilafah ini mau ditegakkan.

Atas dasar beberapa argumentasi di atas inilah akhirnya jika sistem khilafah ini dipaksakan tegak di Indonesia maka akan menimbulkan konflik kebangsaan. Jika terjadi konflik maka kenyamanan, kedamaian dan kemakmuran kehidupan yang selama ini sudah terjalin dengan baik akan rusak. Bila tatanan kehidupan yang sudah damai, rukun dan makmur dirusak maka akan butuh ratusan bahkan mungkin ribuan tahun lagi untuk mengembalikannya.

\section{Implikasi Khilafah Islamiyah terhadap Ukhuwah Wathaniyah}

Atas dasar beberapa wawancara di atas dapat disimpulkan bahwa para ulama Di Bangka Belitung pada dasarnya mengakui adanya khilafah akan tetapi ketika harus ditegakkan di Indoneisa maka disinilah letak perbedaan paham dengan konsep khilafah yang ditawarkan oleh HTI. Hal ini disebabkan para ulama Bangka Belitung masih berasumsi bahwa Khilafah belum cocok ditegakkan di Indonesia karena Negara Indonesia sudah Final yakni sebagai NKRI yang berdasarkan Pancasila dan UUD 1945.

Atas dasar argumentasi tersebut maka jelaslah bahwa jika memang harus ditegakkan khilafah di Indonesia maka akan berimplikasi negatif terhadap ukhuwah wathaniyah di Indonesia. Implikasi negatif ini 
bukanlah berarti konsep khilafah itu tudak baik akan tetapi lebih kepada perbedaan konesp dan perbedaan perspsi tentang khilafah itu sendiri. Ketika dikalangan ulama saja berbeda persepsi tentang khilafah apalagi dikalangan orang awam dan non muslim pasti perebedaan persepsinya lebih tinggi lagi. Jika perbedaan persepsi lebih tinggi maka implikasi negatif terhadap ukhuwah wathaniyah akan makin tinggi pula.

\section{F. Penutup}

Mayoritas persepsi Ulama Bangka Belitung terhadap penegakkan Khilafah Islamiyah sama yaitu mereka berpersepsi bahwa Khilafah di Indonesia masih belum bisa ditegakkan. Adapun beberapa argumentasi yang dapat disimpulkan dari hasil wawancara dengan beberapa ulama Bangka Belitung yaitu : Pertama, Khilafah tidak cocok ditegakkan di Indonesia bukan berarti Konsep Khilafah tersebut tidak baik akan tetapi disebabkan belum ada Kesepakatan atau Ijma' ulama dan juga kesepakatan dengan pemerintah. Kedua, Demi kemaslahatan bangsa dan negara maka untuk saat ini Indonesia tidak baik jika dipaksakan sistem negaranya diganti dengan sistem Khilafah karena sudah ada falsafah sendiri yaitu Pancasila dan UUD 1945. Ketiga, Falsafah negara yang saat ini dipakai juga tidak menyalahi aturan dalam Islam karena falsafah pancasila juga disusun oleh para Ulama Indonesia dan Tokoh Nasional Bangsa Indonesia. Keempat, sudah teruji dan terbukti bahwa Pancasila dan UUD 1945 dapat menyatukan berbagai macam suku, ras dan agama yang ada di Indonesia. Hal ini sesuai dengan semboyannya "Bhineka Tunggal Ika" [.]

\section{REFERENSI}

Fazlur Rahman. Islam. Chicago \& London: The University of Chicago Press, 1982.

Jamal Al-Banna, Runtuhnya Negara Madinah, Islam Kemasyarakatan versus Islam Kenegaraan, terj. Jamadi Sunardi, Yogyakarta, Pilar Media, 2005, n.d.

Muhammad Thoha. Ketua Majelis Ulama Indonesia Kabupaten Bangka Barat, Wawancara, di Muntok, 12 Mei 2017. 
Dedy Alwi dan Ustadz Yanto, S.Pd.I, Pimpinan Ponpes Miftahunnajah, Wawancara, pada tanggal 14 April dan 15 April 2017, n.d.

Hasyim Sya'roni,. Ketua MUI Bateng, 28 April 2017. Koba.

Muhammad Daud Ali, Pendidikan Agama Islam, Jakarta: PT. Raja Grafindo Pesada, 2000, n.d.

Hatamar. diskusi tertutup Pascasarjana IAIN SAS Babel, 23 Maret 2018.

Rachmat Djatmika, Sistem Etika Islam, Surabaya: Pustaka Islam, 1987, n.d.

Riadi, Haris. "Perspektif Taqiyuddin Al-Nabhani Tentang Bai'at," 2014, 14.

Salim bin Ied al-Hilali. Ensiklopedi Larangan Menurut al-Quran dan as-Sunnah, terj. Abu Ihsan al-Atsari. Bogor: Pustaka Imam Syafii, 2005.

Shofwan, Arif Muzayin. "Pandangan Hizbut Tahrir Terhadap Radikalisme Gerakan Isis Dalam Menegakkan Daulah Khilafah." Addin 10, No. 1 (1 Februari 2016): 141. https://doi.org/10.21043/addin.v10i1.1132.

Ustadz Sujoko. Pimpinan Cabang Muhammadiyah Kabupaten Belitung Timur, 18 April 2017. 